\title{
Surplus and Default in Xenophon's Business Economics
}

\author{
Leonardo Paganelli \\ State University of Genoa, Via Balbi 4, 16126 Genova, Italy \\ *Corresponding Author: Leonardo.Paganelli@unige.it
}

Copyright (C) 2013 Horizon Research Publishing. All rights reserved.

\begin{abstract}
Surplus and default are both as old as Man himself. Yet the first work which studies the phenomenon of deficit in a scientific way is Xenophon's Oeconomicus (fourth century B.C.). Conversing with Critobulus, Socrates not only develops a technical nomenclature to denote defaults and losses, but also reveals what to do for transforming them into profits.
\end{abstract}

Keywords Socrates, Xenophon, Default, Business Economics

\section{Introduction: Surplus and Default at the Origin of Business Economics}

«Ma cos'è questa crisi?

(=Butwhat'sthiscrisis?)»

[Rodolfo Tonino "De Angelis", 1933].

It has already been sustained that «accounting would have been impossible without some surplus to take into account». ${ }^{1}$ This is the reason why accountancy originated in Mesopotamia as soon as ancient Mesopotamian peoples because of soil fertility - got some surplus to accumulate.

We have already maintained that accounting is «a mental form a priori of human intellect». ${ }^{2}$ As such, it cannot only reckon profits, but also losses. Modern accountants say that balance may be either «positive» or «negative», registering either a surplus or a default.

Therefore, it happens that - in times of crisis - a clever accountant must register losses more often than profits. Most people think business economics to be useless in times of crisis, when surpluses and profits lack. The contrary is true: during economic depressions, the science of accountancy is even more useful, since it prevents temporary losses from becoming permanent defaults. ${ }^{3}$

\section{Xenophon: The First Nomenclature of Business Economics and Accountancy}

1Cfr. Paganelli 2012 [11], 1227-1228.

2Paganelli 2012 [11], 1227. For further information, we must quote Id. 1992 [9]: perhaps, repeating what we wrote (more than twenty years ago) isn't necessary.

3 See the late Osvaldo Paganelli's doctoral dissertation (1953/54 [12]).
«Xenophon $[\ldots]$ too often irritates the reader by incessant repetition of the same pattern of sentence, of the same formula, and even of the same word. [...] It is strange that he constantly uses the same word over and over again in the compass of a few lines. A translator is often compelled to have recourse to synonyms». ${ }^{4}$

We shan't subscribe to such a severe judgement. Repetitions in Xenophon's Oeconomicus - and especially in the first part of it (chap. I-VI), the so-called Critobulus'Dialogue - denote the effort of creating the nomenclature of business economics and accountancyex nihilo. Elsewhere, we sought to classify the fundamental entries of Xenophon's «lessicocontabile (= accountants' lexicon) $\gg{ }^{5}$ in Greek. Here we are doing the same in English.

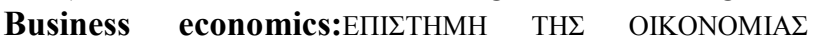
epistēmētēsoikonomias (Oec. I $1 \mathrm{~B}$, VI 4, etc.; Liddell, Scott 1996 [3], 660, 1204; Montanari 2004 [7], 819, 1448). No doubt, OIKONOMIAoikonomia is a most polysemous term. However, when Socrates speaks of ЕПггтнмнтнг

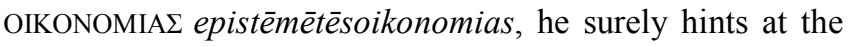
«Science of the OIKOEoikos». Yet OIKONOMIAoikonomia - in Socrates' opinion - isn't a sort of «domestic science» (as some annotators maintain). On the contrary, Socrates' OIKONOMIAoikonomia deals with the nature and function of the OIKOzoikos (the latter being the cell of economic organization). Socrates' innovative change is just considering the OIKOLoikos not merely as a «(family) house», but rather as a prototype of «(family) business» (see enterprise or concern). Only the OIKOzoikos as a business company - we shall note - can be the object of a science which may be compared with medicine: namely, an ЕПггтнмнеpistēmē including a general theory (that's what we call «business economics») and an applied science (that's what we call «accountancy»). It is to be noted, then, that Socrates' OIKONOMIAoikonomia doesn't correspond exactly to modern «economics» as being the science of money. Indeed, today's financial economics is the equivalent of

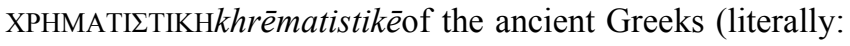
the «science of XPHMATAkhrēmata = capitals»). On the other side, OIKONOMIAoikonomia of the ancient Greeks is closely linked to the notion of OIKOEoikos as a «(family) business»; therefore, it appears to be the equivalent of today’s «business

4Marchant 1923 [5], xxvii.

5Paganelli 1991 [8]; cfr.Gabrovec Mei 1990 [2]. 
$\begin{array}{rrrr}\text { economics and accountancy». } & \text { Now, } & \text { whether } \\ \text { OIKONOMIAoikonomia } & \text { includes } & \text { in } & \text { itself }\end{array}$ XPHMATILTIKHkhrēmatistike (as Socrates maintains at the end of chap. II), or «financial economics» includes in itself «business economics and accountancy», it's a problem much debated by ancient and modern economists.

Business management:OIKONOMIAoikonomia (Oec. I 1 ff.; Liddell, Scott 1996 [3], 1204; Montanari 2004 [7], 1448). Socrates defines OIKONOMIAoikonomia not only as the «science of the OIKOIoikos» (see business economics), but also as the «TEXNHtekhne $=$ art and technique of managing an OIKOEoikos»: that's what we call «management». Of course the act of OIKONOMEINoikonomein, etymologically deriving from OIKONNEMEINoikonnemein (see to manageor administer), isn't the very same as «domestic science», namely housekeeping: on the contrary, it's closely linked with the notion of OIKOEoikos as a«(family) business». No doubt OIKONOMIAoikonomia - in Socrates' opinion - isn't an idle debateon the basic elements of economic theory, but rather a practice. Socrates doesn't accept the distinction (so widespread today) between «business economists» and «business managers or businessmen». According to his ethical intellectualism, the knowledge of business economics is a necessary and sufficient condition to know how to manage a business; and, conversely, the one who doesn't know how to manage an enterprise, proves beyond all doubts that he doesn't know the «science of (business) enterprise».

Capital(s):XPHMA(TA)khrēma(ta) (Oec.I 7 ff.; Liddell, Scott 1996 [3], 2004-2005; Montanari 2004 [7], 2371). Of course, XPHMAkhrēma can't mean «industrial capital», which didn't exist before the Industrial Revolution: it must surely mean «financial capital». In this Dialogue on business management, the notion ofXPHMAkhrēma is strictly related

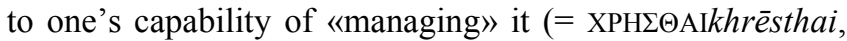
from the same root). Socrates theorizes that not every KTHMAktèma («possession») is a XPHMAkhrēma: only what can be managed is a «capital». Conversely, a KTHMAktēma if one doesn't know how to manage it - is possibly a «possession», but surely not a «capital». It follows that «capital» is an absolute value, whereas «possession» is a

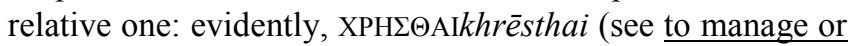
use) and XPHMATAkhrēmata («capitals») are etymologically linked in Socrates' economic theories. No doubt, linking together the ideas of «capital» and «management» is an innovative change - and it seems to occur in Critobulus' Dialogue for the very first time. Business economists ${ }^{6}$ are used to assuming that the origins of the sciences of accounting are to be found at the origins of capitalism: in their view, the first appearance of «industrial capital» would have given rise to early accountancy. On the contrary, we could assert that business accounting originates from the first appearance of «financial capital». If so, the first treatise on accountancy would surely be this Dialogue.

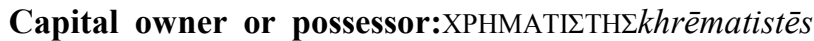
(Oec. II 18; Liddell, Scott 1996 [3], 2005; Montanari 2004

6 We must quote the notable exception of TeodoroD'Ippolito 1960 [1], chap.
[7], 2372). If XPHMATAkhrēmata are «capitals»,

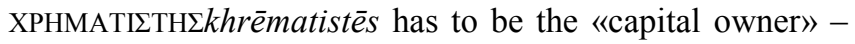
not the «capitalist», since modern capitalism didn't exist yet in fourth-century Athens (that is why Critobulus could never become a skilled «capitalist»). Evidently, ancient XPHMA khrēma was only «financial capital», not «industrial» one: it follows that the science called XPHMATILTIKHkhrēmatistike corresponds to modern «financial economics» (see capitals), whileoIKONOMIAoikonomia is rather similar to our «science of management» (see business economics). Both seem to be closely linked in Socrates' opinion: thus Critobulus becoming a good OIKONOMOEoikonomos (see manager) -

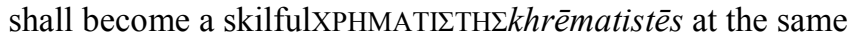
time.

Costs: $\triangle$ AחANAIdapanai, see to expend =

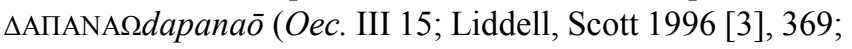
Montanari 2004 [7], 492). In Socrates' opinion, the balance of an OIKOzoikos is based upon economic equilibrium

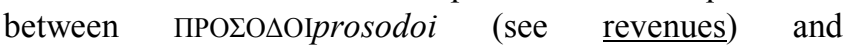
$\triangle$ AחANAIdapanai. In particular, Xenophon thinks that

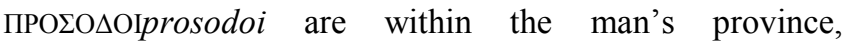
whereas $\triangle$ AПANAIdapanai concern the woman as «joint manageress» of the family business. No doubt, such a division of labour between male and female, husband and wife, would be outdated today - yet it wasn't so in fourth-century Athens. But (what's more surprising) Socrates seems to have already understood - twenty-four centuries ago - that economic equilibrium consists of a positive cost-revenue balance. In other words, $\Pi \mathrm{PO} \mathrm{O} \Delta \mathrm{OI}$ rosodoi must be higher than $\triangle \mathrm{A \Pi ANAI}$ dapanai, so that the difference «revenues minus costs» may be a positive number (ПЕPIOYइIAperiousia: see profit). As concerns that, Socrates is certainly ahead of his time. Now, we have no proof that Xenophon knew something like a «balance sheet» (today consisting in a «statement of assets and liabilities» and a «profit and loss account»). Actually, we know very little about Xenophon's own bookkeeping techniques (it appears that he employs the term $\triangle$ AחANAIdapanai to denote also «expenditure», whilst modern accountancy is used to distinguishing between «costs» and «expenses»). However it might be, we must admit that the essential logic of balance was already clear to Socrates' mind.

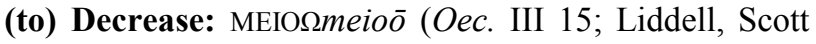
1996 [3], 1093; Montanari 2004 [7], 1318). In business economics, it's the contrary of AY $\Xi \Omega a u x \bar{o}$ (see to expand). As the former means the «decreasing or diminishing» of an enterprise, the latter means its «increasing». In Socrates' opinion, the «decrement» of a business is the result of mismanagement. That happens when the enterprise - instead

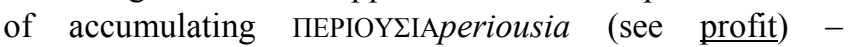
accumulates ZHMIAzēmia (see loss). In conclusion, such «decrement» proves to be due to lack of ЕПгтTHмHepistēme (see science) or EПIME $\Lambda$ EIAepimeleia («attention»).

Enterprise or concern:OIKOEoikos (Oec. I 2 ff.; Liddell, Scott 1996 [3], 1204-1205; Montanari 2004 [7], 1448). No doubt, the most important entry in Xenophon's economic 
nomenclature is this. Its original meaning was «house or family», including the «family estate and/or wealth». Yet, by

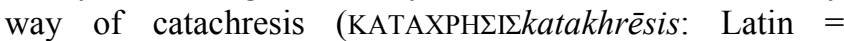
abusio) ${ }^{7}$ Socrates employs this term to signify the «family business or enterprise». Notice that - as time went by - the wordOIKOEoikos lost its affective implications, so as to mean only the «business company or concern or firm», as the basic cell of economic organization. As concerns that, some annotators haven't understood such catachresis, and have

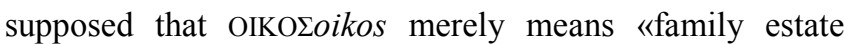
and/or wealth». But this supposition proves to be incorrect, for three reasons. Firstly, Socrates deems the OIKOEoikos to be, not a set of wealth, but a «growing» organism (see expansion), whose value is much greater than the sum of its parts. Secondly, Xenophon maintains that there are most valuable OIKOIoikoi with little wealth (like Socrates' family business) and less valuable OIKOIoikoi with much more wealth (like old Crito's and young Critobulus' family business: see chap. II) - which is the best proof that an OIKOEoikos doesn't identify itself with its wealth. Thirdly, the essence of Xenophon's OIKOzoikos isn't represented by its business wealth, but rather by its business management. Thus the predominance of managerial matters over financial matters is Socrates' innovative change - and this anticipates the theories of modern business economists, in Europe ${ }^{8}$ and especially in the USA. However, the limit of Xenophon's economic thought is that the author wouldn't or couldn't invent a series of neologisms in order to denote the realities $($ German $=$ Realien $)$ of business economics and accountancy: he limited himself to employing the compounds of OIKOEoikos, by way of catachresis (so did the historical Socrates, who was accustomed to discussing the realities of philosophy using terms of everyday speech). But such catachresis has caused many misunderstandings among today's translators and annotators ${ }^{9}$ of Xenophon's OIKONOMIKOEOikonomikos.

(to) Expand:AY $\Xi(\mathrm{AN}) \Omega a u x(a n) \bar{o}(\mathrm{Oec}$. I $4 \mathrm{~B}$, etc.; Liddell, Scott 1996 [3], 277; Montanari 2004 [7], 378-379). It denotes the operation of «increasing and incrementing» a business. Such operation is the ultimate aim of business management. If, at the end of the accounting period, theOIKOEoikos (see enterprise or concern) has accumulated

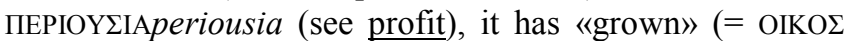
HY $\Xi$ HMENOEoikoseuxeemenos). This is a symptom that the OIKONOMOEoikonomos (see manager) has operated well namely, with EПIME $\Lambda$ EIAepimeleia («attention») and ЕПгттнмнеpistēme (see science). The exact contrary of

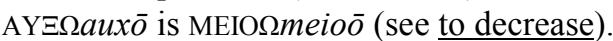

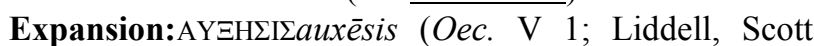
1996 [3], 277; Montanari 2004 [7], 378). It means the «business growth», being the good manager's objective.

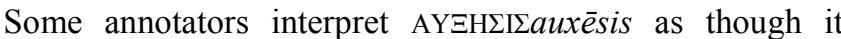
meant only an «increase or increment in wealth». But actually, the business company doesn't identify itself with

7 Cfr. Paganelli 1991 [8], 142-154; Id. 2006 [10], 232-233.

8 Cfr. Paganelli 2012 [11], 1227 n. 5.

9SeeMarchant 1923 [5], xxvii. the business wealth. In fact - according to Socrates - the OIKOEoikos (see enterprise or concern) is a living organism, having in itself the potentiality of growth; on the contrary,

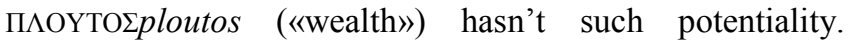
Moreover, Socrates points out that even AРГYPIONargyrion (see money) is no XPHMAkhrēma (see capitals) if one doesn't

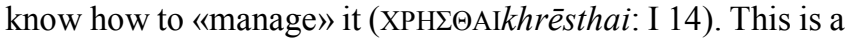
proof that to Socrates' mind, managerial matters are much more important than financial matters, as for what concerns business life.

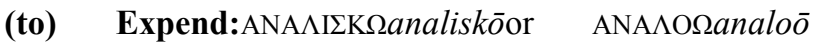

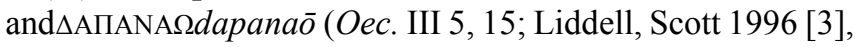
111, 369; Montanari 2004 [7], 184, 492). Both synonyms have a slightly negative meaning. «To spend money» is never a virtue, on the contrary, according to Xenophon's moralism, it may be a vice, if money is expended for unnecessary and/or immoral purposes. As a matter of fact, the author implies that a «good manager» (= OIKONOMO АГАФОГoikonomosagathos: I 2) ought not to spend money for his own sake, but for his business's sake only. As to $\triangle$ AחANANdapanan, it's a typical prerogative of the woman in the family business: yet she must be a good «treasuress», reducing $\triangle$ AПANAIdapanai (see costs) in order to increase ПEPIOYгIAperiousia (see profit) - which operation is called today «spending review», while Xenophon names it TAMIEYMAtamieuma («treasury»).

Gain: KEP $\Delta \mathrm{O}$ skerdos (Oec. III 8; Liddell, Scott 1996 [3], 942-943; Montanari 2004 [7], 1138-1139). Socrates counters

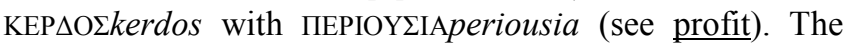
latter is the «net income» obtained by balancing costs and revenues in a skilful way. On the contrary, the former is the «gain or lucre» obtained by buying at a low price and reselling at a high price. Therefore, ПЕPIOYsIAperiousia as such is the result of sound management and the characteristic feature of a good manager. On the contrary, KEP $\triangle \mathrm{O}$ skerdos is the result of retail trade and the characteristic feature of a КАПН $\Lambda$ Ozkapēlos (= «[small] retailer»). This is the reason why Socrates deems MEPIOY IAperiousiato be licit and lawful, whilst other Greek authors consider KEP $\triangle \mathrm{O}$ ¿kerdosas an illicit, unlawful «lucre».

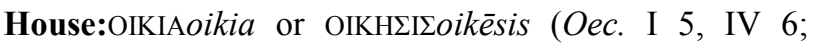
Liddell, Scott 1996 [3], 1203; Montanari 2004 [7], 1447). These two synonyms mustn't be confused with OIKOEoikos (see enterprise or concern). As a matter of fact, OIKIAoikia

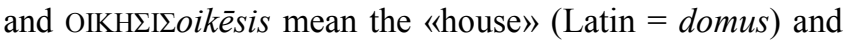
also the «household». Thus comparing the notions of OIKOEoikos and OIKIAoikia, Socrates is obliged to underline a considerable difference between the two. Actually, OIKIAoikia is nothing but the «family house». As to OIKOEoikos, it's something including the «family house» yet something whose limits are far beyond the bounds of the «family house». Some annotators identify the OIKOLoikos with the «family estate», which may extend even to different city-states. However, elsewhere Socrates points out that theoIKOEoikos has also in itself the capacity of «growing» (see toexpand). That is why we have considered it as denoting not merely a sort of «estate», but the earliest form 
of «business enterprise», being the smallest cell of economic organization. So in the history of Greek language, the word OIKOEoikos - formerly concerning a «family» -tends to signify a «family business», and finally a «business company» tout court, like in Modern Greek.

(to) Know:eПILTAmalepistamai (Oec. I 8-17; Liddell, Scott 1996 [3], 658-659; Montanari 2004 [7], 818-819). This is one of the keywords in theDialogue. Firstly, it means the «knowledge of an EПIгTHMHepistēmē» (see science), and secondly the «skill in a TEXNHtekhnē» (see technics ortechnique). The high frequency of this verb gives an intellectualistic tone to Xenophon's Oeconomicus - and indeed, Socrates' ethical intellectualism is witnessed also by Plato and other philosophers. Conversing with Critobulus, Socrates maintains that «knowing the science of business management» is a necessary and sufficient condition for managing a business well. That is why the good OIKONOMOEoikonomos (see manager), in this Dialogue, is so often called EПILTAMENOEepistamenos or

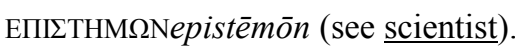

Loss: ZHMIAzèmia (Oec. I 7 B, 9, II 18, etc.; Liddell, Scott 1996 [3], 755; Montanari 2004 [7], 918). It's the exact contrary of ПЕPIOYइIAperiousia (see profit). As the latter is the positive result of business management, the former is the negative difference obtained subtracting $\triangle$ AПANAIdapanai

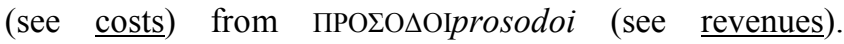
Therefore, as ПЕPIOYгIAperiousia is the characteristics of a good OIKONOMOEoikonomos (see manager), ZHMIAzémia is the typical feature of a bad OIKONOMOEoikonomos - that is to say, a real vice to Socrates' mind, in so far as it derives from an excess of «costs» and a lack of «revenues».

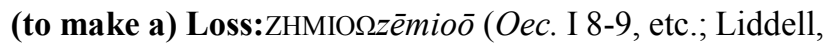
Scott 1996 [3], 755-756; Montanari 2004 [7], 918). Etymologically, it derives from ZHMIAzèmia (see loss), being the typical symptom of mismanagement and maladministration. Socrates maintains that, when KTHMATAktêmata («possessions») are managed «so as to

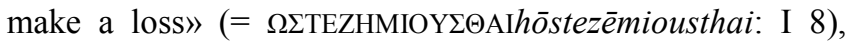
they don't even deserve the very name of XPHMATAkhrēmata (see capitals).

(to) Manage or administer:( $\triangle \mathrm{I}$ ) OIKE $\Omega($ di)oikeō andOIKONOMERoikonomeō (Oec. I 2 B, 4 A, II 13, etc.; Liddell, Scott 1996 [3], 432, 1202-1204; Montanari 2004 [7], $569,1446-1448)$. As for OIKEINoikein, it originally meant «to inhabit or live in». Yet Xenophon uses this verb by way of catachresis (see enterprise or concern), so that the idiom OIKONOIKEINoikonoikein means «to manage a (family) business». Such «management» implies also «business administration, organization, and control». As for $\triangle$ IOIKEINdioikein, this compound is almost a synonym of OIKEINoikein. As for OIKONOMEINoikonomein, etymologically it derives from OIKONNEMEINoikonnemein (= «to dispense food to the OIKOLoikos»), implying that «to manage, administer, and control a (family) business» is a vital function (see business management and manager).

(to) Manage or use: XPAOMAIkhraomaior XPএMAIkhrōmai(Oec. I 7-16, etc.; Liddell, Scott 1996 [3],
2001-2002; Montanari 2004 [7], 2367-2368). The verb means «to use» $($ Latin $=u t o r)$ : Xenophon employs it by way of catachresis (see enterprise or concern), to denote the act of «managing» goods. XPAOMAIkhraomai occurs in this Dialogue very frequently, and this is a proof that the main notion in Socrates' economic theory is «management». No doubt such a practice (see business management) is much more important than «business wealth and/or estate» to the author's mind: cfr. chap. II, where the «sound management» of a small «estate» (that is to say, Socrates' OIKOEoikos) is compared with the «mismanagement» of a large «estate» (that is to say, Critobulus' one). Actually, theorizing the supremacy of «business management» on «business wealth and/or estate» means taking sides, in the economic dynamics,

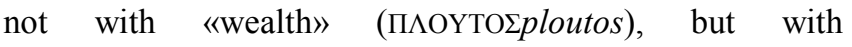
«management or handling of capitals» (= XPHMATA

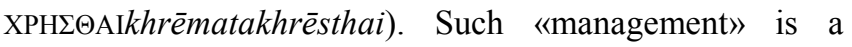
particular form of «labour», employing further «labour» and improving social welfare.

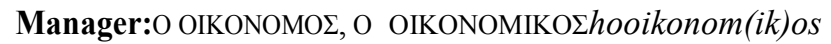
(Oec.I 2-3, etc.; Liddell, Scott 1996 [3], 1204; Montanari 2004 [7], 1448). Another keyword in Critobulus' Dialogue is OIKONOMOEoikonomos, originally meaning the «dispenser (= NEM $\Omega$ Nnemōn $)$ of food in the OIKOEoikos»: that is to say, either the «master (householder)» or the «steward (housekeeper)». By way of catachresis (see enterprise or concern), Xenophon employs this term to denote the «manager of the (family) enterprise», ${ }^{10}$ being also «administrator and controller» of the OIKOLoikos. No doubt the real hero of this Dialogue is the OIKONOMOzoikonomos asanEMПEIPOรempeiros («expert») and an

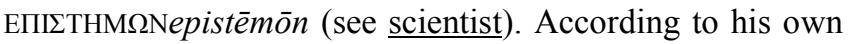
custom (witnessed by Plato too), Socrates refuses the title of OIKONOMOsoikonomos: in fact, although he has understood the principles and laws of the ЕПгтTHMH ТН

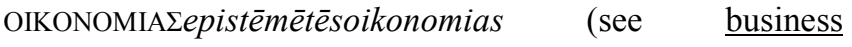
economics), he cannot have the practice deriving from managing a large «business» with big XPHMATAkhrēmata (see capitals). Yet Xenophon's change is maintaining that a «manager» may have full powers over anoIKosoikos (see enterprise or concern), even though he isn't the «owner» and possesses no «capitals» of his own. It follows that - when a business appears to be mismanaged by an incompetent «owner or possessor»-Xenophon counsels to delegate it to a «receiver» (KATA $A B \Omega$ Nkatalabōn: I 4) - namely, a competent OIKONOMOEoikonomos, who will manage it better. Another synonym of OIKONOMOEoikonomos is $\mathrm{O}$

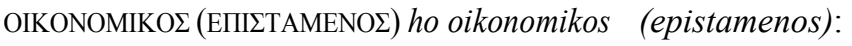
literally, «the specialist in business management».

Money: АРГYPIONargyrion (Oec. I 12-14, etc.; Liddell, Scott 1996 [3], 236; Montanari 2004 [7], 331). The Greek term mostly denoted "silver money» $($ French $=$ argent $)$. Ancient Greeks used to identify АРГУРIONargyrion with XPHMAkhrēma (see capitals). ${ }^{11}$ Yet Socrates' innovative

10Apart from OIKONOMOs, now pronouncedīkonomos, today’s Greeksalso use an English loanword (MANATZEPmanager).

11 Also today's Greeks often do the same (cfr. the song TOXPHMATokhrima, 
change in this Dialogue is the following: even АРГYPIONargyrionis noXPHMAkhrēma, if one doesn't know

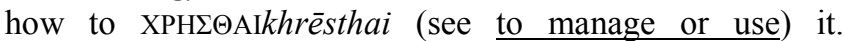
Obviously, the philosopher connects «money»'s value with the owner's managerial skill: if the owner or possessor cannot manage his «money», АРГYРIONargyrion is valueless to him. It follows that the value of АРГУРIONargyrion isn't absolute, but relative, in so far as it depends on one's capability of managing it.

Profit:ПEPIOYzIAperiousia (Oec. I 4 B, II 10, etc.; Liddell, Scott 1996 [3], 1381; Montanari 2004 [7], 1648). This is perhaps the most revolutionary idea expressed in this Dialogue. Deriving from the root of MEPIEIMIperieimi (= «to be over and above [in the margin]; to remain»), ПEPIOYLIAperiousia is the «surplus or positive balance». In arithmetical terms, it's the «remainder or difference» left after the subtraction of $\triangle$ AПANAIdapanai (see costs) from ПРОБО $\Delta \mathrm{OIprosodoi}$ (see revenues). In geometrical terms, it's the «margin». 12 Therefore, Xenophon's ПЕPIOYгIAperiousia is just what today's business economists and accountants call «profit» (UK) or «net income for the period» (USA). It may be rightly defined the «balance» of economic equilibrium - the principle that the total amount of «revenues» must be equal to the sum of «costs» plus ПЕPIOYsIAperiousia was already clear to Socrates, twenty-four centuries ago. On the contrary, if ПEPIOYsIAperiousia is a negative number (see loss), the business account is «unbalanced». It follows that the notion of MEPIOYsIAperiousia implies the existence of a sort of «balance sheet»: Socrates couldn't have spoken of «profits» and «losses», hadn't he known something like a «profit and loss account». Undoubtedly, the Athenian philosopher exalts ПЕPIOYsIAperiousia, defining it the objective of a good OIKONOMOEoikonomos (see manager), the ultimate aim of OIKONOMIAoikonomia (see business management), the «royal road» to ПАОҮТОгploutos(«wealth»), the only lawful «method to make wealth» (ПАОҮТНРONЕРГОNploutēr onergon). In his opinion, MEPIOYsIAperiousia is also the best basis for business appraisal. In fact, chap. II (on OIKOLoikos's valuation) leads to the conclusion that Socrates' OIKOLoikos (see enterprise or concern) has an upward trend, since it makes ПЕPIOYгIAperiousia, whereas Critobulus' OIKOEoikos has a downward trend, since it makes ZHMIAzemia («loss»), being the negative of ПЕPIOYsIAperiousia. And furthermore, while KEPAOskerdos (see gain) may be unlawful to Socrates' mind, ПЕPIOYгIAperiousia is not only lawful, but even a moral duty for the manager. In this Dialogue, the good OIKONOMOEoikonomos is described as a sort of ascetic, renouncing all unnecessary expenses for the sake of ПEPIOY IA periousia.

(to make a) Profit: ПЕPIIOIE $\Omega$ peripoieō (Oec. II 10, etc.; Liddell, Scott 1996 [3], 1384; Montanari 2004 [7], 1651).

by the famous singer $\triangle$ АNАН $Г$ TРАТНГОПОҮ ОYDanaīStratīghopoulou: 1919).

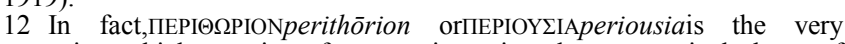
«margin» which remains after superimposing the geometrical shape of «costs» upon the shape of «revenues».
It's a synonym and a derivative of MEPIOYऽIAN ПОIЕ 2 periousianpoieo (see profit). Such operation is an indication of the OIKONOMOEoikonomos's own managerial skill: a good manager can achieve it by decreasing expenditure (see costs: that's what we call «spending review») and increasing income (see revenues). Xenophon (II 10) points out how easy «making high profit from high

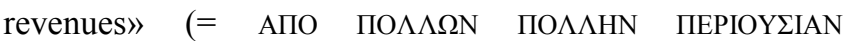
ПОIH乏AIapopollōnpollēnperiousianpoiēsai) can be and how difficult «making a profit from low revenues» (= АП' $\mathrm{O} \Lambda \mathrm{I} \Omega \mathrm{N}$ ПЕРIПOIEINap' oligōnperipoiein) can be.

(to) Programme:MHXANAOMAImēkhanaomai or

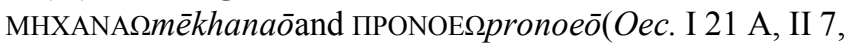
V 18, etc.; Liddell, Scott 1996 [3], 1131, 1490-1491;

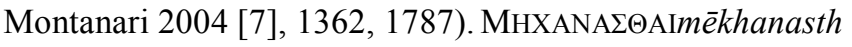
$a i$ - originally a military technicality - denotes the act of «programming» the future «company strategy», «planning» the accumulation of «capitals» (XPHMATAkhrēmata) and «revenues» (ПРО $\mathrm{O} \Delta \mathrm{OI}$ prosodoi). «Company strategy» is compared with military strategy by Xenophon, who was an expert in both. As a disciple of Socrates' intellectualism, he thinks that «programming» requires ЕПІ ТНHН science). Therefore, only a manager who is rich in

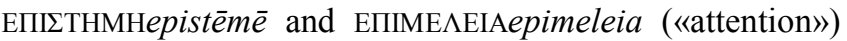
can «plan» the future «company strategy». As to that, a good OIKONOMOEoikonomos (see manager) can be rightly defined the «strategist» of business activity. As for ПPONOEINpronoein, it denotes the act of «forecasting» the future trends of a business. No doubt a manager cannot foresee «unforeseen events» - yet, he needs to have the gift of ПPONOIA pronoia (= «foresight or forethought»): in other words, his NOYsnous (= «intellectual power») must try to «foretell» even the future results of business activity. Once again, OIKONOMIAoikonomia (see business management) is deemed to be an operation of the «intellect», according to Socrates' philosophy.

(lack of) Programme:AMHXANIAamēkhania(Oec. I 21 B; Liddell, Scott 1996 [3], 82; Montanari 2004 [7], 152). Like MHXANAOMAImēkhanaomai (see to programme), also this term is a military technicality. Referred to a business company, it means a situation of «financial straits» due to «lack of (company) strategy». So it's the exact contrary of

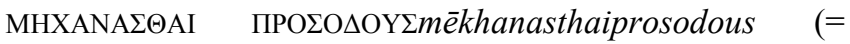

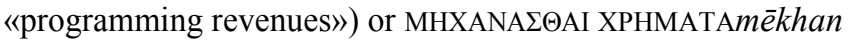
asthaikhrēmata (= «planning the accumulation of capitals»). Socrates connects the idea of «economic crisis» directly with the idea of mismanagement.

Revenues:ПРО $\mathrm{O} \Delta \mathrm{OI}$ rosodoi(Oec. I 21 A, II 11, etc.; Liddell, Scott 1996 [3], 1520; Montanari 2004 [7], 1827). The term denotes «proceeds or revenues» as opposed to $\triangle$ AПANAIdapanai (see costs), but also «income» as opposed to «expenditure» («to expend» $=\Delta$ AПАNA $\Omega$ dapana $\bar{o})$. If ПРО $\mathrm{O} \Delta \mathrm{OI}$ prosodoi are higher than $\triangle \mathrm{A} \Pi \mathrm{ANAI}$ dapanai, the difference «revenues minus costs» is called

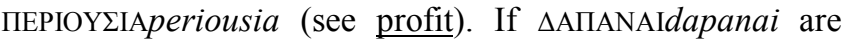
higher than ПРО $\mathrm{O} \Delta \mathrm{OI}$ prosodoi, the difference «costs minus revenues» is called ZHMIAzēmia (see loss). We may conclude 
that Socrates knows of the existence of something like a «profit and loss account». Furthermore, Xenophon maintains that in a family business, «costs» are mainly represented by the woman's activities, whereas «revenues» are mainly represented by the man's «income» (not casually, in III 15 the husband's «proceeds» are denoted by the verb

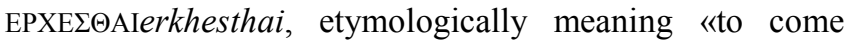
[in]»). Therefore, a family balance is also based on economic

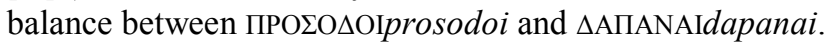

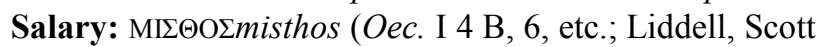
1996 [3], 1137; Montanari 2004 [7], 1368-1369). This is one of the most interesting innovations in Socrates' theory on «business economics» (see business management). He maintains that the OIKONOMOEoikonomos on behalf of third parties (see manager) has the right to get an adequate «salary or fee». Hence derives a sort of contrast between the class of «managers» who aren't business «owners or possessors», and the class of «owners or possessors» who aren't business «managers»: the former being expert professionals, the latter inexperienced amateurs. Undoubtedly, the borderline

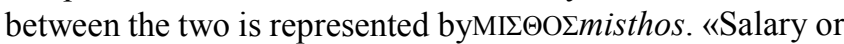
fee» is indeed the distinctive feature of the one who «manages big sums of XPHMATAkhrēmata» (see capitals), even though XPHMATAkhremmata were not of his own. On the

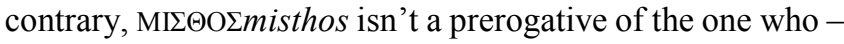
although possessing «capitals» - doesn't know how to

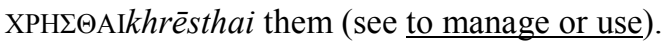

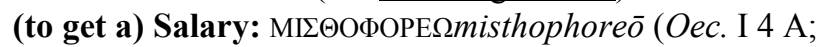
Liddell, Scott 1996 [3], 1137; Montanari 2004 [7], 1369). «Obtaining a fee» is a most sacred right of the professional in OIKONOMIAoikonomia (see business management).

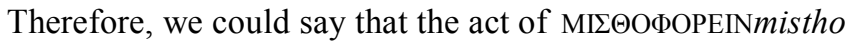
phorein gives birth to the profession of OIKONOMOEoikono mos (see manager). Yet, this implies that the management of an OIKOEoikos (see enterprise or concern) may be withdrawn from an «incompetent» and ignorant owner, and delegated to a «competent» manager, who gets a salary because of that. Socrates' change is just this sort of opposition (not to say «conflict») between the class of OIKONOMOIoikonomoi and the class of KEKTHMENOIkektēmen $o i(=$ «owners or possessors»).

Science:ЕПгтнннеpistèmē (Oec. I 1 B; Liddell, Scott 1996 [3], 660; Montanari 2004 [7], 819). This notion was a great favourite of Socrates', as Plato too testifies. In this Dialogue, Socrates states that also OIKONOMIAoikonomia (see business economics) is an ЕПгтTHMHepistèmē, since it's the «science of business management». This means that - up to Xenophon - the management of OIKOIoikoi had been conducted in an amateurish way. From Xenophon onwards, business administration (see business management) becomes the subject of a «science», the prerogative of professionals.

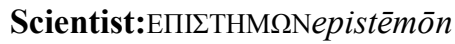

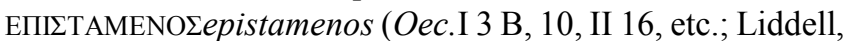
Scott 1996 [3], 658-660; Montanari 2004 [7], 818-820). The term denotes the one who possesses ЕПгІтнмНерistème (see science): namely, the «scientist» as opposed to the ЕMПЕIPOรempeiros («expert»), whose prerogative is to have skill and «experience» (EMIEIPIAempeiria), and also as

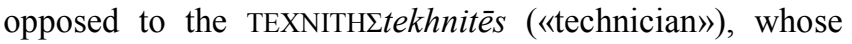
prerogative is to have TEXNHtekhne (= «art»: see technics or technique). According to Socrates, the OIKONOMOsoikonom os (see manager) must not only be a professional, but also a real «scientist», versed in economic studies. In other words, today's contrast between theorists and practisers in «business management» - namely, between business economists and managers - isn't validated by this Dialogue: it did not exist (and should not exist) according to Socrates.

Standard of life:_IAITAdiaita (Oec. II 8 A; Liddell, Scott 1996 [3], 396; Montanari 2004 [7], 525). It's the result of individual «expenditure», rather than of individual «income». Socrates indeed underlines that men with high «incomes» often have $\Delta$ IAITAIdiaitai beyond their means, since their «expenses» are even higher than their «proceeds»

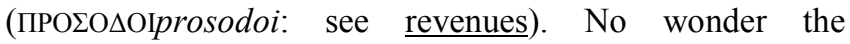
philosopher advisesCritobulus to reduce his «standard of life», it being too high, and to decrease «expenditure» (that's what we call «spending review»), limiting $\triangle$ AПANAIdapanai (see costs) to the mere «necessaries» (TAEחITHAEIAta epitēdeia or TAANAГKAIAta anankaia).

Technics or technique: TEXNHtekhnē (Oec.VI 6-7; Liddell, Scott 1996 [3], 1785; Montanari 2004 [7], 2111-2112). The term denotes «manual arts» and «handicraft technics» as well. One of the main ideas expressed by

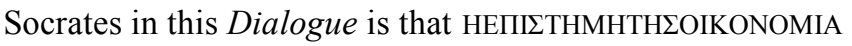

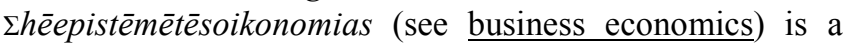
TEXNHtekhne, in so far as it is the «art and technique of business administration». As well as other «techniques» (such as XA^KEYTIKHkhalkeutike $=$ «metallurgy», TEKTONIKHtektonike = «tectonics», and so on), it requires skill, EПIMЕ $\Lambda$ EIAepimeleia («attention»), EMПEIPIAempeiria («experience»), and also special ОРГАNAorgana («instruments»), namely XPHMATA (see capitals). From Xenophon onwards, OIKONOMIAoikonomia (see business management) becomes a «technology» - the specialty of professionals (OIKONOMOIoikonomoi) being not only «artisans», but also «artists».

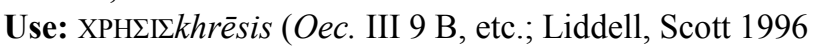
[3], 2006; Montanari 2004 [7], 2372-2373). This is another important entry in Xenophon's business nomenclature. It means not only the «use», but also the «way of managing things inside a business». Socrates's idea of «management» had almost been forgotten in the Middle Age. It was revived during the Italian Renaissance, thanks to Lucas Paciolus and Leon Battista Alberti (author of De Iciarchia, a treatise on the «government» of the OIKOLoikos). ${ }^{13}$ Hence modern business economics and accountancy were derived from it. The Athenian Socrates, therefore, can rightly claim to be the inventor of this concept, which has been widely developed by today's Business Schools (especially in the USA).

\section{Conclusion: «Thou Shalt Rule over It»}

13Albertipronounced OIKO§īkos, like modern Greeks do today. 
«There come seven years of great plenty

throughout all the land of Egypt;

and there shall arise after them seven years of famine; and all the plenty shall be forgotten in the land of Egypt; and the famine shall consume the land».

[Genesis, XLI 29-30 (King James Version, 1611)].

Crises, deficits and defaults-in so far as they are recurring in human history - are ineluctable. But since the time Socrates discovered the science of business economics and accountancy, such science has not only aimed at registering, but also at controlling them. Ancient business economists and accountants were already able to diagnose deficits; yet their diagnosis was only the first step towards therapy. Just like in the field of medicine, ancient peoples from the Sumerians up to the Greeks studied the phenomena of economic crises in order to cure them scientifically. They deemed default to be a sort of economic pathology, but believed they should «rule over it». ${ }^{14}$ So did Socrates, according to which a default is always an effect of maladministration and mismanagement.

\section{Appendix: AGreek Index}

This Greek reverse index has been compiled in order to favourthose readers who don't know ancient Greek (in fact, it follows the English order of words instead of the Greek alphabetical one). ${ }^{15} \mathrm{We}$ are sure it mayfacilitate their consultation of the English nomenclature listed above (§ 2).

AmēkhaniaAMHXANIA = (lack of) Programme

Analiskein $\mathrm{ANA} \Lambda \mathrm{IKEIN}=($ to $)$ Expend

Argyrion $\mathrm{AP}$ ГYPION $=$ Money

$\operatorname{Aux}($ an) $\operatorname{ein} \mathrm{AY} \Xi(\mathrm{AN}) \mathrm{EIN}=($ to $)$ Expand

Auxēsis AY $\Xi \mathrm{H} \Sigma I \Sigma=$ Expansion

Dapanai $\triangle \mathrm{A} \Pi \mathrm{ANAI}=\mathrm{Costs}$

Dapanan $\triangle \mathrm{A} \Pi \mathrm{ANAN}=($ to $)$ Expend

Diaita $\Delta$ IAITA $=$ Standard of life

(Di) oikein $(\Delta \mathrm{I})$ OIKEIN $=($ to $)$ Manage or administer

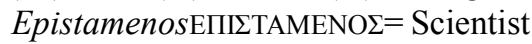

Epistasthai $\mathrm{E} \Pi \Sigma \mathrm{TA \Sigma} \Theta \mathrm{AI}=($ to $)$ Know

Epistēmēen

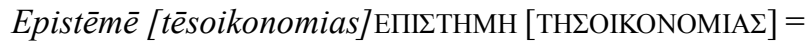

Business economics

Epistēmōn $\mathrm{E} I \Sigma \mathrm{THM} \Omega \mathrm{N}=$ Scientist

KerdosKEP $\triangle \mathrm{O} \Sigma=$ Gain

Khrēma(ta) $\mathrm{XPHMA}(\mathrm{TA})=$ Capital $(\mathrm{s})$

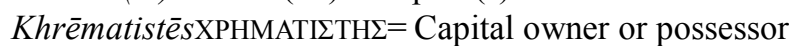

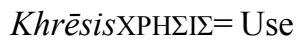

KhrēsthaiXPH $\mathrm{\Theta AI}=$ (to) Manage or use

Meioun MEIOYN= (to) Decrease

Mēkhanasthai $\mathrm{MHXANA \Sigma} \Theta \mathrm{AI}=$ (to) Programme

Misthophorein $\mathrm{MI} \Theta \Theta \Phi$ OPEIN $=($ to get a) Salary

Misthos $\mathrm{M \Sigma} \mathrm{\Theta O} \Sigma=$ Salary
Oikein OIKEIN $=$ (to) Manage or administer

Oikēsis $\mathrm{OIKH} \Sigma \mathrm{I} \Sigma=$ House

OikiaOIKIA $=$ House

OikonomeinOIKONOMEIN=(to) Manage or administer

OikonomiaOIKONOMIA= Business management

OikonomikosOIKONOMIKO $=$ Manager

OikonomosOIKONOMOs= Manager

OikosOIKO $=$ Enterprise or concern

PeriousianEPIOYsIA= Profit

Peripoiein $\Pi$ EPIחOIEIN= (to make a) Profit

Pronoein $\Pi$ PONOEIN= (to) Programme

Prosodoi $\Pi \mathrm{PO} \mathrm{\Sigma O} \triangle \mathrm{OI}=$ Revenues

TekhnēTEXNH= Technics or technique

ZèmiaZHMIA $=$ Loss

ZèmiounZHMIOYN= (to make a) Loss

\section{REFERENCES}

[1] Teodoro D'Ippolito. Documenti per lo studio storico delle dottrine di ragioneria, Vol. I, Abbaco, Palermo-Roma, 1967.

[2] Ondina Gabrovec Mei. Il linguaggio contabile. Itinerario storico e metodologico, Giappichelli, Torino, 1990.

[3] Henry George Liddell, Robert Scott, Henry Stuart Jones, Roderick McKenzie. A Greek-English Lexicon, 9th ed. (New Revised Supplement), OxfordUniversity Press, Oxford, 1996.

[4] Mario Liverani. Antico Oriente. Storia, società, economia, Laterza, Roma-Bari, 1988.

[5] Edgar CardewMarchant, [Oliver Julian Todd]. Xenophon, Vol. IV: Memorabilia, Oeconomicus, Symposium, Apology, Loeb, London-Cambridge MA., 1923.

[6] Federigo Melis. Storia della ragioneria, Zuffi, Bologna, 1950.

[7] Franco Montanari. Vocabolario della lingua greca-GI (Greco-Italiano), 2nd ed., Loescher, Torino 2004.

[8] Leonardo Paganelli. Senofonte e il linguaggio contabile, Lexis, Vol. VII-VIII, 135-154, 1991.

[9] Leonardo Paganelli. Un dialogo sul management (Senofonte, Oec.I-VI), Cisalpino, Milano, 1992.

[10] Leonardo Paganelli. Socrate economista, in Il messaggio socratico nella storia dell'umanità, 225-238, Acadèmia, Bologna, 2006.

[11] Leonardo Paganelli. Origins of Business Economics and Accountancy, in Proceedings in Advanced Research in Scientific Areas. ARSA Virtual Conference, 1227-1232, EDIS, Zilina, 2012.

[12] Osvaldo Paganelli. La determinazione del reddito in ipotesi di variabile valore della moneta, Diss. State University of Bologna, Re.: Teodoro D'Ippolito, Università degli Studi di Bologna, Bologna, 1953/54.

14Cfr. Genesis, IV 7 (King James Version, 1611): «Thou shalt rule over it». 15 Examples: khix-though being one of the last letters in the Greek alphabet-is listed immediately after kappaK; Greek verbs are listed under the infinitive, etc. 